\title{
DE MIRADAS Y HERIDAS. HACIA LA DEFINICIÓN DE UNOS MODELOS DE ESTILIZACIÓN EN EL CINE ESPAÑOL DE LA POSGUERRA $(1939-1950)^{1}$
}

\author{
José Luis Castro de Paz \\ Universidade de Santiago de Compostela
}

\begin{abstract}
RESUMEN
Tras años de investigación sobre el cine español de la posguerra, este trabajo plantea por vez primera la articulación teórica e historiográfica de cuatro Modelos de estilización para el periodo 1939-1950 (sainetesco-costumbrista; obsesivo-delirante; paródico-reflexivo y formalista-pictórico), resultado de los diversos y estéticamente fructíferos cruces entre las normas narrativas y visuales ya internacionalizadas a través de Hollywood y las populares tradiciones culturales españolas (teatrales, literarias, pictóricas, musicales) que constituían -transformadas ya al contacto con el nuevo medio- el más fértil material nutriente de nuestro cine desde el periodo silente, pero bajo la presión ahora de un contexto histórico y político especialmente sombrío y complejo. Dichos Modelos no son sino armas metodológicas que intentan dar orden discursivo a lo que en los filmes aparece casi siempre mezclado, y contribuir al más profundo conocimiento de un cinema herido, a la vez humorístico y desolado, costumbrista y melancólico, reflexivo y espectral.
\end{abstract}

Palabras clave: cine español de la posguerra, Modelos de estilización, costumbrismo, humor, melancolía, reflexividad.

\section{ABSTRACT}

After years of research on the Spanish postwar cinema, this work presents the first theoretical and historiographical articulation of four styling models (sainetesco-costumbrista; obsessive-delusional; parodic-reflective and formalisticpictorial) for the period 1939-1950, resulting from the diverse and aesthetically successful crosses between narrative and visual standards already internationalized through Hollywood and popular Spanish cultural traditions (theater, literature, painting, music) that became -once transformed through the contact with the new medium- the most fertile nutrient material of our cinema since the silent period, but now under the pressure of a particularly grim and complex historical and political context. Such models are only but methodological weapons trying to provide a discursive order to what usually appears mixed in films, and to contribute to the deepest understanding of a wounded cinema, but also humorous and desolate, traditional and melancholy, reflective and spectral.

Keywords: Spanish postwar cinema, styling Models, costumbrismo, humor, melancholy, reflexivity.

\section{Introducción: cine español de la pos- guerra y Modelos de estilización.}

Después de más de dos décadas investigando el cine español del primer decenio posbélico ${ }^{2}$ y una vez minuciosamente analizado el corpus de filmes del periodo, escrutados sus procedimientos formales, sus complejos modos de reelaboración de las populares tradiciones culturales de las que parten para seducir a sus potenciales espectadores asegurándose su lealtad y, en de- finitiva, la respuesta textual que proponen ante las predeterminaciones con las que se encuentran en tan oscuro periodo histórico; ${ }^{3}$ conocidas la complejidad y riqueza de un cine tan desigual como poblado de títulos de incontestable altura estética y cultural, y constatado en fin que también en nuestro ámbito -como había ocurrido en arquitectura, pintura o literatura y nos anunciaban desde mucho tiempo atrás nuestros colegas historiadores de dichos campos artísticos- 
existían no sólo "excepciones", sino tendencias, corrientes y "generaciones" que se esforzaban por continuar un trabajo cultural tan dificultoso como meritorio que había dado ya sus primeros, escasos y sabrosos resultados fílmicos durante la Segunda República, ${ }^{4}$ creemos estar en disposición de intentar responder a la pregunta nodal que latía en el corazón mismo de nuestras indagaciones: ¿Cómo definir y analizar unos Modelos de estilización del cine español? ¿De qué manera continuar profundizando en el estudio de su peculiar y diferenciada textura?

Partimos -hemos de insistir en ello- del convencimiento de que el cine posbélico español fue capaz de ofrecer, pese a tan adversas circunstancias históricas, nuevas y variadas (a menudo densas, siempre condicionadas) formulaciones fílmicas capaces de conjugar, en permanente disputa textual, los ya internacionalizados dispositivos narrativos y visuales del Modo de Representación Institucional (MRI), ${ }^{5}$ de matriz hollywoodiense y expansión internacional imparable desde finales de la Primera Guerra Mundial, con esa corriente subterránea común -auténtico humus o savia nutricia de nuestro cine- constituida por ciertas tradiciones populares teatrales, literarias, plásticas y musicales del arte español. Si Santos Zunzunegui fue en su día capaz de establecer preliminarmente cuatro destacadas vetas creativas en el cine hispano en función de la manera de entender el concepto de estilización ${ }^{6}$ sus realizadores esenciales, ${ }^{7}$ nuestra voluntad es la de historiarlas en un periodo concreto (1939-1950), construyendo unos Modelos de estilización específicos, resultado de los peculiares entrecruzamientos de las convenciones más o menos asimiladas del MRI con los motivos y las formas culturales propias tal y como se desarrollan singularmente en tan sombrío y turbio momento histórico.

Se trata de poner en pie una guía interna, teórica e historiográfica, capaz de estructurar y ordenar los objetos del corpus precisamente para que sus analogías y diferencias se dibujen con mayor nitidez. Si en efecto cada película es única e irrepetible, los Modelos de estilización son construidos por el historiador del cine no para colocar en cómodas casillas las realizadas en un periodo dado -de hecho ninguna encar- nará de manera nítida y plena un Modelo, pues estos solo existen teóricamente- sino, bien al contrario, con el fin de dar orden discursivo a lo que en los filmes aparece mezclado, de "elaborar tendencias virtuales y proyectos espectaculares en (...) [dicho] periodo" y de entender en profundidad la complejidad y las presiones sufridas por los textos estudiados. ${ }^{8}$ Partimos, previa y lógicamente, del detenido análisis fílmico de las películas conservadas, centrado en los más importantes aspectos de su configuración formal: puesta en escena (tratamiento figurativo, construcción del espacio, dispositivos y recursos del montaje, formas interpretativas, estilemas más constantes y llamativos), estructuras narrativas y enunciativas y preferencias semánticas, así como en la influencia en ellas de otras formas culturales y artísticas -como cierta pintura, ${ }^{9}$ novela o teatro españoles-, también determinantes en sus configuraciones textuales.

Insistamos de nuevo en que la práctica totalidad de las películas realizadas en España entre 1939 y 1950 participan de la mayoría de los rasgos del MRI y en que, en consecuencia, nuestros Modelos de estilización solo podrán surgir de las intransferibles (de)formaciones - de los fructíferos frotamientos- de tales dispositivos al contactar con unos materiales de partida determinados en un oscuro tiempo histórico no menos concreto y específico. Un ejemplo nos ayudará aquí. Si como es sabido el MRI se caracteriza, grosso modo, como un sistema esencialmente narrativo, donde prima la construcción de férreos elementos ficcionales, ocultándose el trabajo de montaje/puesta en escena -dado que todos los dispositivos fílmicos se hallan subordinados a los intereses narrativos-, y con el espectador como centro privilegiado al que no debe escapársele, en cada instante, aquello que es relevante para la comprensión del relato, en el caso español dicha primacía de la historia viene a chocar frontalmente, no pocas veces, con una muy peculiar estilización de nuestras formas interpretativas más características, produciendo jugosas rugosidades y productivos cruces, incluso en aquellas comedias que, casi siempre al amparo de una CIFESA en fase de máximo esplendor y organizada al modo norteamericano, se quieren directamente vinculadas al modelo de la comedia sofisticada hollywoodiense (Deliciosamente tontos, 
1943, Tuvo la culpa Adán, 1944, La vida empieza a medianoche, 1944, Yo no me caso, 1944 o Ella, él y sus millones, 1944, de Juan de Orduña; La tonta del bote, 1939, Los millones de Polichilena, 1941, Un marido a precio fijo, 1942, La boda de Quinita Flores, 1943 o Cristina Guzmán, 1943, todas ellas de Gonzalo Pardo Delgrás, o El hombre que las enamora, 1944, de José María Castellví, entre otras). Así, por ejemplo, no debe extrañar que la citada Ella, él y sus millones se convierta en uno de los filmes españoles de más éxito en la temporada 1944-1945, pero ello sin duda no solo se debe (o no esencialmente) a su descolorida imitación del diseño de producción de la alta comedia americana -con los lujosos decorados de Enrique Alarcón bañados con una iluminación en exceso fría y uniforme-, sino por un trabajo sobre los registros interpretativos y la velocidad del recitado de los diálogos que, aun proveniente del Howard Hawks de La fiera de mi niña (Bringing Up Baby, 1938) o Luna nueva (His Girl Friday, 1940), toma cuerpo en un reparto que, con José Isbert a la cabeza, sitúa al filme en la línea de lo desmesurado y lo grotesco, violentando el "original" y conduciéndolo por nuevos e irrepetibles derroteros creativos. En otras palabras, su "enloquecimiento" y sofisticación han de ser analizados -tal es la peculiaridad de la gestualidad del cuerpo y la voz de algunos de sus actores- a partir del conocimiento de unos parámetros culturales del todo diferentes a los de sus referentes hollywoodienses. ${ }^{10}$

Señalemos también, de partida, cómo el que quizás constituya el más llamativo, sorprendente y relevante rasgo formal del cine posbélico español debe situarse -tal es su trascendencia cuantitativa y cualitativa- por encima de los Modelos, sobrevolándolos todos y colándose, de formas diversas y en distintos grados, en cada uno de ellos. Se trata de su decidida voluntad autoconsciente, reflexiva y metacinematográfica. ${ }^{11}$ En efecto, la constante presencia de efectos deconstructores que desvelan de algún modo el carácter artificioso de la representación, si bien tiene que ver con algunos de los populares espectáculos matrices de nuestro cine (y es detectable desde el periodo mudo), así como con la literatura del coruñés Wenceslao Fernández Flórez, cuyas numerosas adaptaciones en la época pesan mucho en su generalización (El hombre que se quiso matar, Rafael Gil, 1942; Intriga, Antonio Román, 1943; El destino se disculpa, José Luis Sáenz de Heredia, 1945), puede rastrearse en los más variados filmes del periodo, desde en las tempranas, alocadas y eficaces comedias arrevistadas de Ignacio F. Iquino (¿Quién me compra un lío?, 1940) o las sorprendentemente anarquizantes parodias metafílmicas de Ramón Barreiro (El sobrino de don Búfalo Bill, 1944; El Pirata Bocanegra, 1946) hasta en la concepción narrativa de algunas otras de las más características comedias de la década (por ejemplo, la crítica y corrosiva Dos cuentos para dos, Luis Lucia, 1947), pasando -entre muchas y muy diversas manifestaciones que podrían ponerse- por el demiúrgico y asfixiante sistema textual del denso melodrama de ambientación histórica Locura de amor (Juan de Orduña, 1948). Dicho fenómeno, que anticipa un proceso similar que solo se produce en el cine hollywoodiense después de la Segunda Guerra Mundial, viene a cuestionar, una vez más, el supuesto retraso de la cinematografía española en relación con la evolución internacional de la estética fílmica y parece posible poder vincular su omnipresencia con los desgarramientos formales producidos por una psíquicamente devastadora contienda fratricida.

\section{Modelos de estilización en el cine pos- bélico español.}

Cuatro son los Modelos que hemos podido detectar y caracterizar en el cine español realizado entre 1939 y 1950 como resultado -digámoslo una vez más- de la compleja hibridación tras la Guerra Civil del internacional MRI con las tradiciones populares que habían constituido el sustrato último del cine español desde sus mismos inicios: un Modelo de estilización sainetesco-costumbrista (MESC), resultado del frotamiento del cinematógrafo con algunas de las más socialmente arraigadas tradiciones de las tablas y el espectáculo teatral españoles (sainete, género chico, zarzuela...) y que representan en el periodo estudiado, mejor que ningún otro, ciertos títulos de la filmografía de Edgar NeviIle; un Modelo de estilización obsesivo-delirante (MEOD), tendencialmente vinculado al género melodramático y formado por películas presididas por una mirada masculina herida por la pérdida del objeto amoroso y que, a lo largo de su 
desarrollo, presentarán la formalización radical del delirio del sujeto (Vida en sombras, de Lorenzo Llobet-Gràcia, 1948, habrá de constituir uno de sus ejemplos más nítidos y acabados); un Modelo de estilización paródico-reflexivo (MEPR) basado esencialmente en una cómica, absurda, excéntrica y artificiosa estilización paródica de la verosimilitud aparentemente realista del MRI; $y$, finalmente, un Modelo de estilización formalistapictórico (MEFP), vinculado a películas cuya diégesis suele centrarse en célebres acontecimientos históricos y caracterizado, en especial, por su tendencia a la sucesión de cuadros vivientes elaborados a partir de una tradición visual -principalmente pictórica, citándola muchas veces de modo literal-casi siempre bien conocida por el público (Locura de amor sería, aquí, el ejemplo medular).

\section{2a. Modelo de estilización sainetesco- costumbrista.}

Pese a que su embrionaria puesta a punto comienza ya en el periodo mudo (y El pilluelo de Madrid, Florián Rey, 1926; ;Viva Madrid, que es mi pueblo!, Fernando Delgado, 1928 o El sexto sentido, Nemesio M. Sobrevila, 1929, surgen, incluso, de sainetes escritos originalmente para la pantalla), ${ }^{12}$ no parece caber duda de que tanto los sainetes y las "tragedias grotescas" del alicantino Carlos Arniches como la literatura humorística, melancólica, crítica y popular de Fernández Flórez (que moderniza y urbaniza, desplazándolo al tiempo hacia la deprimida y casi inexistente clase media, a ese personaje tipo de españolito de a pie en cierta forma proveniente del sainete) $)^{13}$ constituyen algunos de los pilares básicos en la configuración -dramáticamente sesgada por la Guerra Civil- de un cine "nacional-popular" republicano capaz de amalgamar y reformular esas tradiciones adaptándolas a los gustos y las necesidades del pueblo en un momento histórico determinado.

El extraordinario arraigo y la complejísima consolidación de este tipo de cine en los años cuarenta (pese a ser durísimamente criticado por amplios sectores del régimen franquista a los que recuerda una "república de horteras, leandras y gorras proletarias", considerándolo despreciable mugre "radical-socialista") y en décadas poste- riores, hace que sea este, sobre todo de la mano de Edgar Neville -que precisamente había iniciado su carrera en el periodo republicano con El malvado Carabel (1935, adaptación de la novela homónima de Fernández Flórez) y La señorita de Trevélez (1936, a partir de la célebre "tragediagrotesca" de Arniches)-, el único de los Modelos de estilización propuestos que se identifica casi absolutamente con una de esas cuatro destacadas vetas creativas del cine español establecidas por Zunzunegui. Se trata de aquella que "hace suya una específica forma de excentricidad en relación con los cánones típicos (y tópicos) del realismo, basada sobre la noción de popularismo casticista" ${ }^{14}$ y que tiene en los cartones para tapices de Goya y en los sainetes dieciochescos de Ramón de la Cruz sus más nítidos orígenes, pese a que, lógicamente, sus raíces se hundan en formas culturales más antiguas y encuentren más tarde en el sainetero Carlos Arniches su representante más célebre y fecundo.

Los resultados del contacto de esas formas teatrales sainetescas (estructura coral; verismo costumbrista que no siempre se anclará al presente del rodaje para evitar problemas con la censura; escenarios que representan lugares comunales y públicos; multiplicidad de episodios; gracejo y frescura de unos diálogos cargados de gags lingüísticos, retruécanos, y juegos de palabras; uso de técnicas costumbristas, [ambientación, actitudes externas de los personajes a través de la interpretación, etc.]; condición social y laboral humilde de los protagonistas que viven en los barrios más bajos; participación de actores extraordinariamente populares que encarnan "tipos" que van más allá de las obras concretas y con inaudita capacidad para improvisar variaciones al contacto con la temperatura cómica y emocional del público) ${ }^{15}$ y literarias con el cinematógrafo español trae consigo "consecuencias" creativas de primer orden que, aunque como vimos se perfilaban ya desde el periodo silente, solo alcanzan ahora verdadera estilización fílmica.

En tal proceso, los elementos "internacionales" (vinculados al MRI) de los que parte el Modelo (incluso genéricamente, pues no olvidemos que los filmes de Neville que más nítidamente lo encarnan son también singulares cruces con 
elementos policíacos en parte "importados") se modulan y transforman en profundidad hasta producir sustanciales particularidades en todos y cada uno de los campos analizados. Así, por ejemplo, el montaje/puesta en escena mostrará tendencialmente un llamativo predominio de composiciones plásticas amplias, de populosos planos generales y de conjunto (para dar cabida a ese mundo coral y "público", abigarrado de humildes relaciones cotidianas), lo que traerá consigo a su vez la atenuación de la fragmentación clásica y un porcentaje mayor de planos secuencia y movimientos de cámara de los comúnmente presentes en la fragmentación analítica del MRI y, por lo tanto, una (relativamente) menor dependencia del engarce por raccord. En otras palabras, se producirá una disminución mayúscula del análisis del espacio, dada la confianza en el reconocimiento espectatorial de los lugares-tipo (corralas, plazas del pueblo, mercadillos, verbenas...) donde se agolpan y relacionan las gentes que pueblan los escenarios (y el Modelo mismo). Desbordantes de vida y movimiento, los encuadres se ven sobrepasados por sus cuatro lados, sin que se preste demasiada atención a la composición geométrica y al cuidado de los límites del cuadro (se ha llegado a hablar de "descuido" compositivo, de películas tan mal hechas como la vida española), incluso si a veces dicha característica parece entrar en contradicción con la inspiración pictórica (Francisco Goya, José Gutiérrez Solana) de algunos de sus ejemplos señeros.

En lógica continuidad con lo señalado, y provenientes de ese tipificado universo popular, las estructuras narrativas son generalmente esquemáticas, y las situaciones puro pretexto para que un narrador próximo y humanista, solidario con las clases que describe, se recree con delectación en el castizo lucimiento de actitudes, diálogos (madrileñistas-arnichescos, andalucistasquinterianos, etc.), formas y movimientos de los intérpretes. Dada la coralidad que las preside, se atenuará extraordinariamente la dependencia del héroe protagonista, y predominará la presencia, sobre el clásico galán, de actores (mal llamados) secundarios o de reparto (Antonio Vico, Valeriano León, Antonio Casal, Manolo Morán, Fernando Fernán-Gómez, Guadalupe Muñoz Sampedro, Julia Lajos, Irene Caba Alba, etc., cuya escuela in- terpretativa, surgida del teatro popular sainetesco, la zarzuela, las variedades o la revista, difiere por completo de las formas naturalistas del MRI) que pueblan con el singular materialismo ibérico de sus cuerpos y sus rostros esos planos amplios y tumultuosos.

Aunque elementos del MESC aparecen en un elevado número de títulos del periodo que estudiamos (dirigidos por cineastas como Benito Perojo, Florián Rey, Rafael Gil, José Luis Sáenz de Heredia, Ignacio F. Iquino, Jerónimo Mihura, Gonzalo Pardo Delgrás...) la obra que mejor lo encarna -engarzándolo con los preludios republicanos y convirtiéndolo en punta de lanza para su fértil bifurcación en los años cincuenta- ${ }^{16}$ es la de Edgar Neville. Su filmografía, solidamente asentada sobre una tradición sainetesca y costumbrista que no olvida empero la vanguardista influencia de Ramón Gómez de la Serna, el "regeneracionismo" de su amigo Ortega y Gasset y las lecciones de su trabajo en Hollywood a comienzos del sonoro, constituye un fundamental proceso de reformulación de tales elementos, de consecuencias decisivas para la historia del cine español. Títulos como el cortometraje Verbena (1941), La torre de los siete jorobados (1944), Domingo de carnaval (1945) o El crimen de la calle de Bordadores (1946) suponen algunas de las más sólidas aportaciones de su autor a "la recreación de un imaginario matritense decimonónico desde las categorías del relato costumbrista y los personajes castizos, representativos de un específico sentir nacional surgido de las clases populares". ${ }^{17}$

Narrativamente desaliñada y plásticamente inspirada en cierta pintura costumbrista de Goya, en las pinturas carnavalescas de su gran amigo José Gutiérrez Solana (que llega a visitar el rodaje y muere poco antes del estreno) y quizás también en los grabados del mismo tema de Ricardo Baroja, Domingo de carnaval, habrá de servirnos brevemente como excepcional muestra del Modelo que tratamos de definir. En ella, sainete madrileñista y criminal y carnaval "bajtiniano"18 se funden en sabio mestizaje, y la ligereza de estilo y hasta el (supuesto) descuido de la puesta en escena de Neville se convierten en excelentes mecanismos de representación de un mundo popular y espontáneo no circunscrito 
idealmente a los límites del encuadre, desbordando éste por todos sus lados, al modo, valga la expresión, de la anticlásica dispersión característica de lo popular-carnavalesco. Consciente de que la extraordinaria densidad popular de (las raíces de) su estilo tenía sus más robustos pilares tanto en la interpretación de los actores (Fernando Fernán-Gómez, Conchita Montes, Joaquín Roa, Guillermo Marín, Julia Lajos; y en sus cómicos y a veces absurdos diálogos, de raíz arnichesca pero influenciados a su vez por Ramón y por los humoristas compañeros de Neville en la "Otra Generación del 27") como en la muy cuidada reconstrucción de los ambientes, el disparatado argumento original (el asesinato de la "prendera" doña Reme a manos de un sereno

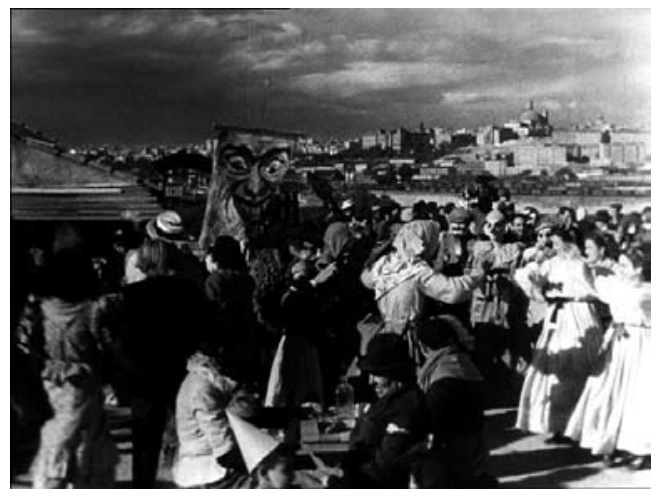

Fig. 1. El entierro de la sardina en la Pradera de San Isidro. Plano general, de claras influencias goyescas y solanescas, en Domingo de Carnaval (Edgar Neville, 1945)

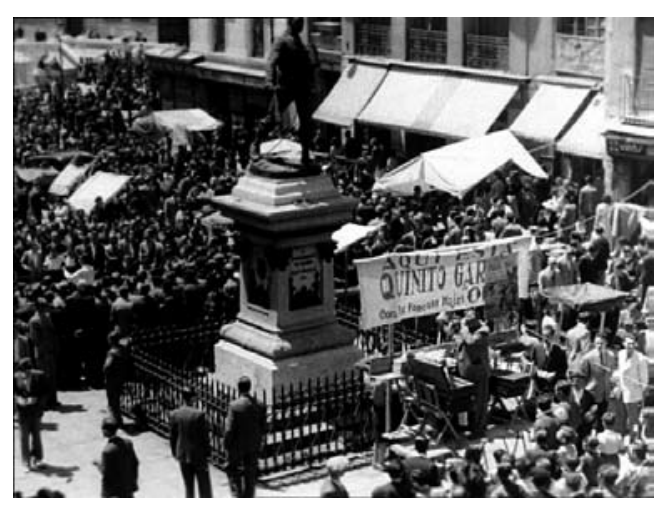

Fig. 2. Gran plano general, picado, sobre la multitud que se agolpa en la Plaza de Cascorro. Domingo de Carnaval (Edgar Neville, 1945) gallego) se convertía en manos del cineasta en simple hilo narrativo con el que tejer la puesta en escena, de sorprendente autenticidad, del Rastro madrileño, sus gentes y ambientes, durante las fiestas de Carnaval de finales de los años diez del siglo XX. Rodada en exteriores naturales, el evidente predominio de planos amplios, generales y de conjunto -que caracterizan el Modeloresponden con lógica al carácter coral del film y al bullicio popular de sus enclaves principales (EI Rastro, la Plaza de Cascorro, la Pradera de San Isidro) y engloban varios personajes de extracción popular, generalmente solidarios entre sí (como las vendedoras que ayudan a Nieves, la protagonista, vendedora de relojes "isabelinos", en su particular investigación para demostrar la inocencia de su padre). En la mayoría de los casos, la cámara se ubicará naturalmente en medio de los transeúntes, y a medida que se diluya la trama policiaca, el tomavistas se centrará sin subterfugios en la vívida recreación del ambiente festivo, ofreciéndonos amplias composiciones, densamente populares y sin finalidad narrativa alguna, de las calles atestadas de gente, deteniéndose incluso largamente en los desternillantes discursos de los "charlatanes" (los auténticos vendedores del rastro en 1945, aunque el film se ambiente treinta años antes, cuando el carnaval no estaba prohibido) para vender sus productos. Fértil conjugación de elementos, en fin, puestos en juego por un narrador culto y popular decidido a densificar la verdad antropológica del fondo que bulle por detrás de la tópica acción principal (Fig. 1, Fig. 2)

\section{2b. Modelo de estilización obsesivo- delirante.}

Se trata del Modelo más nítidamente marcado por el momento histórico en el que surge, desarrollándose casi en exclusividad en el periodo estudiado para desaparecer en la década siguiente, en la que solo con esfuerzo podríamos rastrear ejemplos aislados de algunas de sus características. Con todo, buena parte de sus películas más representativas (Las inquietudes de Shanti Andía, 1946, y Obsesión, 1947, de Arturo Ruíz-Castillo; Embrujo, 1947, y La sirena negra, 1948 de Carlos Serrano de Osma, Cuatro mujeres, 1947, de Antonio del Amo, La fiesta sigue, 1948, de Enrique Gómez, la ya citada 
Vida en sombras, 1948, de Llobet-Gràcia o Ha entrado un ladrón, 1949, de Ricardo Gascón ${ }^{19}$ ) pertenecerían asimismo a la veta mítica establecida por Zunzunegui, dado que las reflexiones que proponen -tal es su altura estética y semántica- alcanzarán de lleno en ocasiones, incluso más allá del trascendental anclaje histórico de las historias narradas en el tiempo de su realización, a las heridas psíquicas del deseo masculino vinculadas al conflicto edípico y al complejo de castración descritos por Sigmund Freud y reformulados por Jacques Lacan. ${ }^{20}$ Tampoco por casualidad dichas cintas pertenecen en su mayoría a las filmografías de directores que comienzan a sus carreras en las segunda mitad de la década, formando parte de generaciones y grupos (los "renovadores", los "telúricos") singularmente preocupados por la estética cinematográfica y muy alejados de lo que se suponía un cine proclive a los intereses del régimen franquista.

Sin renunciar a la presencia (incluso mayoritaria) de dispositivos propios del MRI, conformarían el MEOD -como adelantábamos- aquellos títulos formalmente organizados en torno a una mirada masculina obsesionada y herida por la pérdida del objeto amoroso ${ }^{21}$ (en ocasiones nítida y sombría metáfora de la guerra), incapaz de enfrentarse al duelo, melancólica hasta el delirio. Ambientadas casi siempre en una enrarecida y espesa nocturnidad urbana, llama la atención en ellas la búsqueda decidida de formulaciones visuales extremas de un espacio (y un clima) denso, malsano, agobiante, dolorosamente irrespirable,

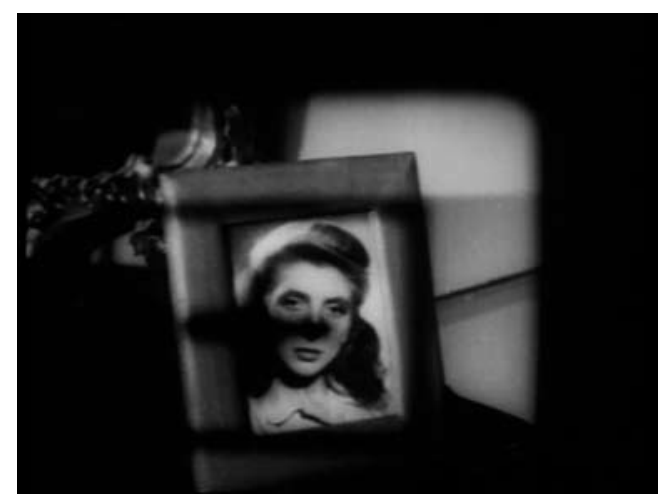

Fig. 3. La mirada del hombre, a través de la cámara de cine, a la fotografía de su mujer fallecida (Vida en sombras, Lorenzo Llobet-Gràcia, 1948) de claras resonancias psicoanalíticas. Complejos planos-secuencia y movimientos y/o posiciones muy visibles de la cámara, secuencias de montaje, sobreimpresiones y todo tipo de llamativos efectos visuales al margen de cualquier mesura clásica entroncan el Modelo (incluso si algunos de sus referentes confesos se encuentran en los más "experimentales" cineastas de Hollywood, como Orson Welles, Alfred Hitchcock, Fritz Lang o Robert Siodmak) con las tradiciones visualistas de las vanguardias fílmicas europeas de los años 20 y 30 (expresionismo alemán, montaje soviético impresionismo francés). De hecho, el narrador parece compartir con su personaje, herido y hondamente melodramático, cierto nerviosismo apasionado, de forma que aun pretendiendo desvincularse de su locura emocional, se imbrica en ella irremediablemente.

Vinculadas generalmente al género melodramático -aunque incluso comedias tan relevantes como Huella de luz (1942) o Eloísa está debajo de un almendro (1943), ambas de Rafael Gil, o películas de ambientación histórica como la oscurísima Inés de Castro (1944) de Leitao de Barros y M. A. García Viñolas, recogen en algunos segmentos sus más graves constantes-, las películas presentarán siempre, en alguno o varios momentos de su desarrollo, la formalización fílmica de una mirada masculina que delira su objeto de amor perdido, en ocasiones a partir de representaciones fotográficas, cinematográficas o pictóricas de la desaparecida (Fig. 3, Fig. 4). Esta presencia-ausencia femenina (pues el fan-

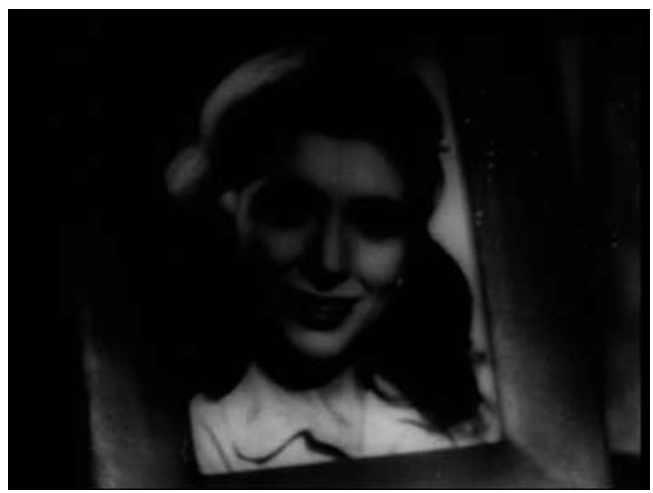

Fig. 4. El delirio de la mirada. La fotografía sonríe (Vida en sombras, Lorenzo Llobet-Gràcia, 1948) 
tasma de la mujer muerta, desaparecida o traidora continúa forjado a fuego en el inconsciente del sujeto), y en definitiva la imposibilidad de la satisfacción del deseo masculino, tal como nos la ha explicado la teoría psicoanalítica, se conjugan inextricablemente, de forma más o menos explícita, con el doloroso presente posbélico del rodaje, para hablarnos, metafóricamente y en distintos grados, de la miseria sexual franquista. Este hueco alcanza asimismo, tendencialmente, a la estructura narrativa, que suele ocultar (el trasunto diegético de) la escena primordial, bien situándolo previamente al comienzo de la trama (aunque determine por completo el devenir de esta), bien elidiéndolo bruscamente por medio de elipsis tan angustiosas como desconcertantes, a menudo subsanadas por un tan aparentemente resolutivo como falsamente curativo flash-back. ${ }^{22}$

Aunque en la puesta en forma de esa mirada melancólica y delirante no suele ocupar un destacado papel cuantitativo la subjetividad óptica, se recurre en ocasiones al punto de vista subjetivo del hombre, muchas veces para abortarlo o subvertirlo inmediatamente, pero convirtiéndolo por ello en excepción de marcadísima intencionalidad (que incluso encierra el inicio del delirio mismo). En cualquier caso, en parte continuando la abierta tendencia mostrativa de nuestro cine desde el periodo mudo, en parte para evitar asemejarse a la subjetividad hitchcockiana de Rebecca (1940), durísimamente considerada como morbosa, materialista y herética por parte de la más poderosa y oficialista crítica cinematográfica española del momento, ${ }^{23}$ los cineastas más mesurados y menos radicales buscarán alternativas a la "peligrosa" ortodoxia del plano subjetivo por medio de un tratamiento del espacio del plano (tamaño, composición "pictórica", iluminación, profunda estilización de los decorados, etc.) que lanza sobre el mismo una carga metafórica que se asocia, sin partir de él, con la melancolía del personaje. Estrictamente, esta peculiarísima subjetividad atmosférica (que el triunvirato formado por el director Rafael Gil, el fotógrafo Alfredo Fraile y el decorado Enrique Alarcón llevará a su más excelsa expresión en la magistral El clavo) se caracteriza antes por la focalización en el personaje y la subjetiva indirecta libre que por el uso (muy restringido) del plano subjetivo y, a su vez, interactúa con una llamativa y constante presencia de un enunciador que participa y comenta los acontecimientos narrativos, en ocasiones dando la sensación de un tormento igual o mayor que el de los actantes.

En la sombría adaptación de la novela de Emilia Pardo Bazán La sirena negra -menos conocida pero tan ejemplar para nuestro Modelo como Vida en sombras, en la que el delirio "fotográfico" del cineasta Carlos Durán (FernandoFernán Gómez) partía tanto del visionado de Rebecca de Alfred Hitchcock como de la revisión de la propias películas familiares en las que aparecía su mujer, muerta durante las primeras escaramuzas bélicas en Barcelona-, solo el tardío flashback que narra el trágico suicidio juvenil de la Mujer (la amada, la desaparecida, la sirena negra a la que delira en el agua y busca reencontrar en otros cuerpos) aclara en cierto nivel narrativo el decimonónico y trágico deambular de Gaspar de Montenegro (otra vez Fernando Fernán-Gómez), personaje castrado, incompleto y vacío, melancólico, incapaz en última instancia de cerrar la pérdida del objeto materno, esencialmente irrecuperable, y abocado por ello a una búsqueda tan obsesiva como vana en la que la mirada, incapaz de rendirse al dolor de la ausencia, creerá fugazmente encontrar otros cuerpos donde posar el fantasma. La siempre fallida elección de la(s) sustituta(s) (la joven muerta, Rita) depende menos de la mujer misma que del fantasma que el hombre coloca sobre ella, siendo la desilusión y el dolor -dolor de vivir-el resultado de tan vano trayecto de representación en representación. "Reflexión sobre las jurisdicciones del deseo proyectado sobre un objeto sin otra fisonomía que la pasión delirante", 24 la densidad fílmica de $L a$ sirena negra proviene -no podía ser de otra manera- de la extrema brillantez significante de sus resoluciones visuales, de una puesta en forma de sombría y asfixiante opacidad, que tiene en Orson Welles y en Alfred Hitchcock algunos de sus principales referentes.

En este sentido, sorprende sobremanera comprobar cómo Serrano de Osma es capaz de anticipar en una década la solución formal ideada por Hitchcock en Vertigo (1958) a la hora de dar forma a la mirada masculina que, reconociendo el cuerpo al que no puede evitar 


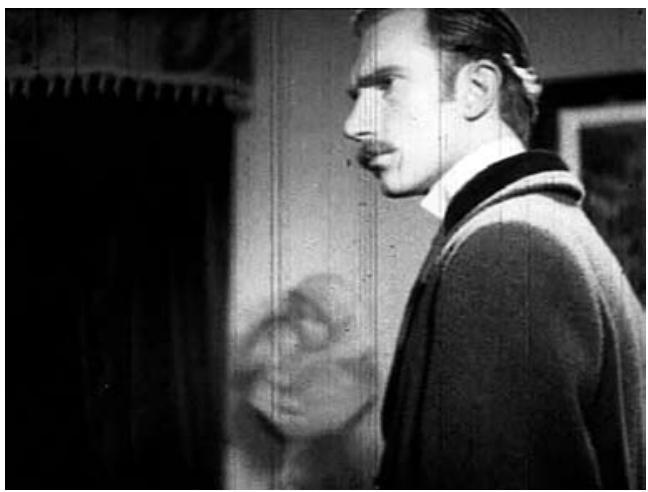

Fig. 5. Desde el perfil del hombre, una panorámica subjetiva hacia la mujer (La sirena negra, Carlos Serrano de Osma, 1948)

dirigirse, se lanza hacia él, atraída y temerosa. En ambos casos un plano semisubjetivo surge de la mirada de los protagonistas para, en panorámica, encuadrar el rostro de la mujer; entonces, dejando los ojos atrás, un travelling de aproximación señala el inicio mismo de ese proceso irreversible de ensamblaje entre el cuerpo elegido y los fragmentos de imágenes primordiales que tejen nuestro deseo inconsciente para dar nueva (y no menos fugaz) vida al fantasma. (Fig. 5, Fig. 6, Fig. 7, Fig. 8). Y aunque a diferencia de Hitchcock Serrano de Osma no busca construir en ningún momento el férreo proceso de identificación protagonista-espectador que Vertigo pone en pie por medio del hipertrófico recurso al punto subjetivo del personaje interpretado por James Stewart,

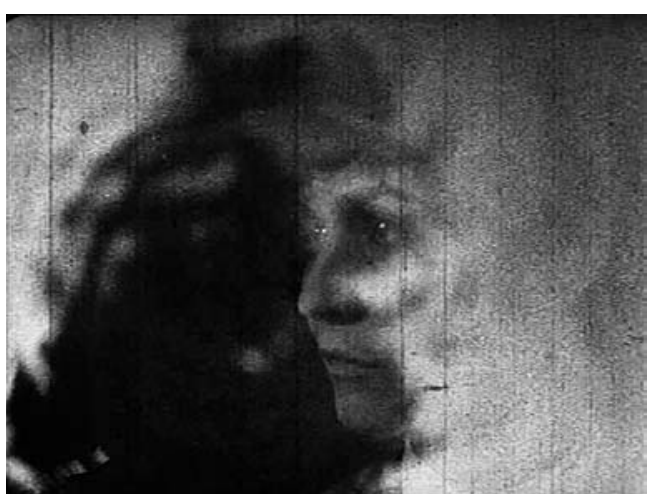

Fig. 7 Ensamblaje entre el cuerpo y el fantasma (La sirena negra, Carlos Serrano de Osma, 1948)

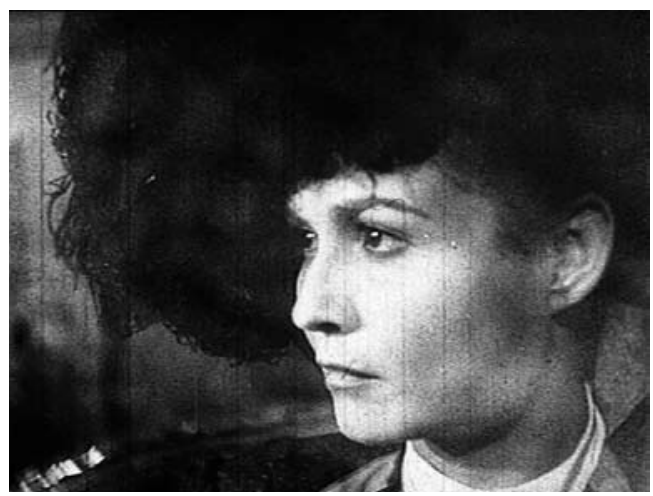

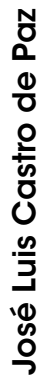

Fig. 6. Primer plano, semisubjetivo, de Rita, el cuerpo elegido (La sirena negra, Carlos Serrano de Osma, 1948)

no deja por ello de recurrir reiteradamente al de Gaspar de Montenegro, aproximándonos así a la angustia del protagonista al obligarnos a compartir su mirada. Pero -a diferencia de las resoluciones hitchcockianas-, Serrano anticipa siempre (bien a través de movimientos de cámara, bien por medio de planos ad hoc) el centro de atención dramática de cada secuencia, antes incluso de que en ella repare la delirante mirada del protagonista. Disolviendo así el punto de vista único, el texto se tensa y densifica hasta extremos inauditos. Romántico(s) hasta la extenuación, protagonista y enunciador entrelazan sus miradas que, sin embargo, no acaban nunca de converger. Ambas atraviesan la diégesis rozándose a veces, divergiendo otras, siempre a la búsqueda de ese ansiado

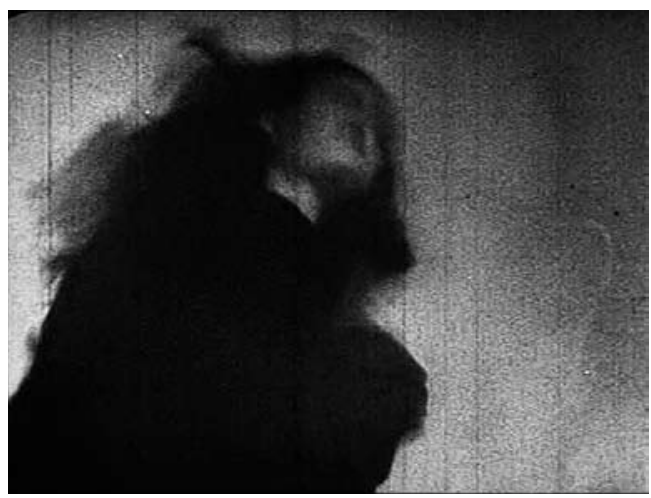

Fig. 8 El delirio (La sirena negra, Carlos Serrano de Osma, 1948) 
plano infinito wellesiano. Y no extraña, por ello, que obligado Gaspar por la censura a casarse con la insulsa Trini (a la que por supuesto no desea), el narrador le preste su cámara y su poder para abandonarse en una dolorosa caída a las rocas, metafóricamente mortal.

En definitiva, puede afirmarse que la singularísima especificidad del Modelo de estilización obsesivo-delirante se debe a la conjunción de ciertos temas universalmente melodramáticos con las soluciones concretas de puesta en escena por medio de las cuales ciertos cineastas encararon, tras la contienda bélica, los problemas formales que tales temas suponían en el contexto de la España de la época. La heterodoxia formal, la influencia de la vanguardia (y del más moderno cine norteamericano) y la consecuente excentricidad con relación al MRI conformaron el extraño trenzado de un tejido sobre el cual la herida bélica española alcanzó, quizás, su más coyuntural, llamativa y excelsa estilización.

\section{2c. Modo de estilización paródico- reflexivo.}

Surgido de la compleja mezcolanza resultante de la frotación con el cinematógrafo de elementos provenientes del propio sainete, del astracán de Muñoz Seca o de García Álvarez, ${ }^{25}$ del humor absurdo y vanguardista practicado desde los años 20 en la revistas ilustradas, en el teatro y en la novela por autores como Miguel Mihura, Antonio de Lara "Tono", Enrique Jardiel Poncela, José Santugini o el propio Edgar Neville (humoristas de la "Otra generación del 27"), pero también de la zarzuela cómica, las parodias (de obras teatrales serias) y las humoradas generalizadas en el madrileño teatro por horas, de la revista y los espectáculos de variedades, ya durante el periodo mudo y los años republicanos (Una aventura de cine, dirigida por Juan de Orduña a partir de un guión original de Fernández Flórez en 1927; las piezas fílmicas de Ramón Gómez de la Serna y Ernesto Giménez Caballero, la célebre trilogía de cortometrajes Una de fieras, 1934, Una de miedo, 1935 e Y, ahora, una de ladrones, 1935, dirigidas por Eduardo García Maroto a partir de guiones de Mihura), el Modelo de estilización paródico-reflexivo alcanza su formalización y más intenso desarrollo en la inmediata posguerra coincidiendo significativamente en el tiempo el estreno de algunas de sus más piezas más representativas con la aparición de la célebre revista de humor La codorniz (1941, dirigida inicialmente por Mihura).

Voluntariamente artificioso, farsesco, caracterizado por una excéntrica estilización paródica que recurre de cualquier modo a la puesta en solfa de la verosimilitud aparentemente realista del MRI, vulnera, distanciado y juguetón, todas y cada una de sus normas. Desde el punto de vista narrativo, el desarrollo lineal y causal característico de la narración clásica (aunque no de todo el cine hollywoodiense, sin duda; los hermanos Marx, por ejemplo, también aportan sustanciales gotas a la desternillante salsa resultante que es el MEPR) deja lugar al devenir absurdo y delirante de gags, juegos de palabras y diálogos disparatados y astracanescos, números musicales y/o situaciones paródicas extremas. En ocasiones incluso autores como Shakespeare o Calderón de la Barca se convertirán en disculpa sobre la que poner en pie la función; en otras, más nítidamente metacinematográficas, los propios géneros del cine clásico serán los elegidos para mejor dinamitar burlonamente sus lógicas internas.

Aunque partiendo de las convenciones clásicas, el montaje/puesta en escena del MEPR forzará la transparencia espacio-temporal y la tendencia al borrado de las huellas de la enunciación con burlona violencia. Los llamados "signos de puntuación" convencionales, por ejemplo, reaparecerán aquí a menudo pero, dejando de lado cualquier funcionalidad, lo harán como inauditos protagonistas de una especie de orgía de efectos semánticamente intrascendentes, a la busca de un non sense estrictamente formal; los decorados, por su parte, parecen llegar a pervertir del todo su función tradicional (y cualquier aspiración "realista"), convertidos en casos extremos en burdos telones pintados, o agrandados o transformados de los modos más insospechados y disparatados. Por su parte, la interpretación de los actores -aunque conjugándose a veces en el mismo film (y hasta en el mismo plano) con formas costumbristas, produciéndose insólitos resultados de tales mixturas- se aparta totalmente del naturalismo clásico, buscando la más llamativa y cómica excentricidad histriónica y burlona. 
Pero quizás la más desternillante singularidad del MEPR es la de, con altísima frecuencia, partir del propio cine como sujeto-objeto de juegos y chanzas reflexivas y metacinematográficas (de las que no se libra ni el obligatorio doblaje ni la posibilidad del subtitulado), a la vez tan cómicas y desvergonzadas como virulentas y distanciadoras, soliendo primarse todos aquellos aspectos susceptibles de realzar y poner de relieve el estatuto del filme como representación. En ocasiones, por ejemplo, se recurre, a la hora de poner en escena acontecimientos del pasado, al uso de recursos del cine mudo (ausencia de diálogos, didascalias, fundidos en ojo de buey, uso del plano de conjunto primitivo, interpretación exagerada de los personajes, música de piano al modo de las que acompañaban las imágenes en el periodo silente, etc.) (Fig. 9). Asimismo, y proveniente en buena medida -aunque entre otras muy variadas fuentes- del teatro de (y de las piezas fílmicas escritas por) Miguel Mihura, así como de la transposición al cine de las modernas particularidades materialistas de la escritura humorística de Jardiel Poncela (adaptado en el periodo, por lo demás, en títulos más o menos concomitantes con algunos aspectos del modelo: Los ladrones somos gente honrada, Ignacio F. Iquino, 1942, y Eloísa está debajo de un almendro, Rafael Gil, 1944), el propio medio cinematográfico se convierte en motivo central de la parodia que las películas ponen en pie. Así, por ejemplo, casi al final de Intriga (Antonio Román, 1943, basada en una novela de Fernández Flórez y con diálogos de Miguel Mihura), la cámara gira sobre

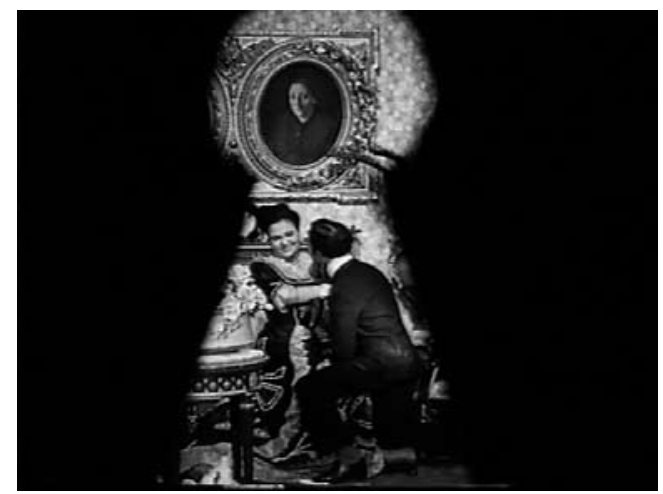

Fig. 9 Plano ojo de la cerradura, al modo del cine primitivo, en Viaje sin destino (Rafael Gil, 1942) si misma para descubrir al director y su equipo como auténticos culpables de tan enrevesada (y paródicamente ridícula) trama criminal; en Viaje sin destino (Rafael Gil, 1942, con guión de José Santugini), una pantalla de cine es el medio para controlar desde el sótano el funcionamiento del espectáculo de casa de terror que se ofrece a los turistas (Fig. 10); en la recién citada Los ladrones somos gente honrada, una cámara cinematográfica oculta servirá a la policía para resolver el (paródico) caso...

Una voice-over narradora externa a la diégesis -que tiene en la seminal El hombre que se quiso matar (1942) uno de sus primeros ejemplos en el largometraje de ficción (también internacionalmente) ${ }^{26}$ y que, proveniente en parte del recurso cómico mihuresco ya ensayado en la república, se cruza en la España posbélica con el hábito de lectura espectatorial de voces similares en el noticiario bélico-, llega dolorida para quedarse y presidir los relatos, narrándolos a modo de fábula o cuento (como luego sucederá en algunas de las más destacadas películas españolas de la década siguiente, de ¡Bienvenido, Mister Marshall!, Luis García Berlanga, 1953, con participación de Mihura en el guión, a Calle Mayor, Juan Antonio Bardem, 1956, inspirada en la arnichesca "La señorita de Trevélez"), aunque no faltarán tampoco en el Modelo narradores decididamente paródicos, descreídos o descerebrados, burlones y cómplices, que ejercen de maestros en estas ceremonias del absurdo. Del mismo modo que los personajes miran a la cámara, y son conscientes de la presencia del tomavistas

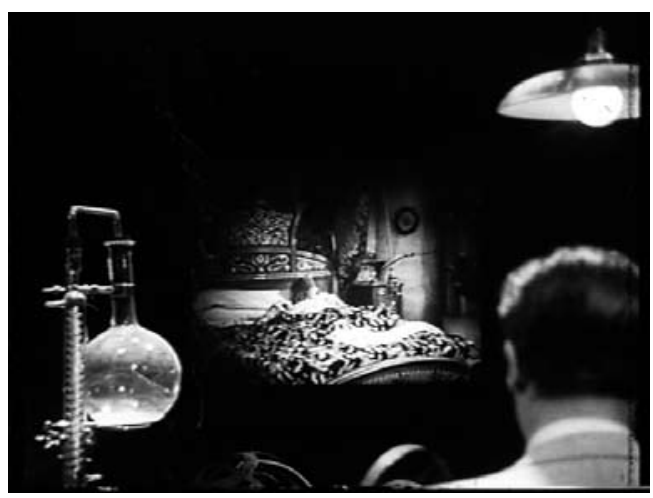

Fig. 10 Una secreta pantalla de cine para vigilar a los huéspedes en Viaje sin destino (Rafael Gil, 1942) 
y del realizador, interactuando entre ellos de modos diversos, el Modelo requiere asimismo la lúdica participación de un espectador que disfruta del galimatías narrativo y visual con más o menos regocijo en función de sus conocimientos y expectativas.

Además de las obras citadas, y de otros ejemplos tan tempranos y llamativos como Los cuatro robinsones (Eduardo García Maroto, 1939), quizás el ciclo más completo de películas que podemos situar en el MEPR sean los títulos rodados por Ignacio F. Iquino, en su mayoría para Campa-CIFESA, entre 1940 y 1944, como ¿Quién me compra un lío? (1940), El difunto es un vivo (1941), Boda accidentada (1943), Un enredo de familia (1943), Viviendo al revés (1943), Fin de curso (1943) o Ni pobre, ni rico, sino todo lo contrario (1944) muy vinculadas a su vez con el espectáculo arrevistado de "El Paralelo" barcelonés. Pero, por su desconocida y excéntrica radicalidad, preferimos referirnos ejemplarmente a Pototo, Boliche y compañía (1948), última película y muestra extrema de la peculiar y humorística reflexividad paródica de su autor, el ya citado realizador gallego Ramón Barreiro. ${ }^{27}$ El título supone en su filmografía la definitiva ruptura de toda convención narrativa y visual, desvelando una y otra vez los dispositivos retóricos puestos en juego en el texto y con breves apariciones confusamente diegéticas de los más famosos actores de la época, haciendo de ellos mismos mientras escuchan la radio, o de críticos y de otras personalidades del mundo del cine y del deporte que acuden a una comida organizada por la película (y dentro de esta, por la cadena de radio) y rodada a modo de "reportaje de sociedad". E incluso el propio Ramón Barreiro aparecerá como el vendedor de armas que surte al anarquista León Boliche (José Jaspe), en una secuencia delirante.

En torno a un ligerísimo y enloquecido argumento -el cobro de una herencia familiar depende de que Boliche sea capaz de hacer rentable primero y hundir económicamente después en un tiempo record una cadena radiofónica en España, mientras un primo anarquista intenta boicotear el plan con todo tipo de artimañas-, más próxima al cartoon americano que a la típica comedia de herencia y enredo que tanto había proliferado en España desde el final de la Guerra Civil -y es que esa era casi la única manera de hacer comprensible al público el enriquecimiento repentino, verdadero happy end para el español de entonces-, la película es una entretenida astracanada metalingüística de extraordinario interés que -como todo magazine radiofónico que se precie, pues de un exitoso programa de radio provienen los personajes- cuenta además con las actuaciones del Trío Calaveras, el Cuarteto Drim, Antoñita Moreno, Pacita Tomás y José Morató.

La voice-over, por ejemplo, no sólo se refiere a su propia inutilidad en determinada secuencia, observando que su presencia se debe a una moda pasajera, sino que no se resiste a señalarnos explícitamente el error del guión al hacer que León Boliche entre por la ventana en las oficinas de la emisora, después de haber obligado a su novia Maribel (Maribel Alonso) a robar la llave de la misma ("Esto es un fallo de raccord", advierte socarrón el narrador). Y, en algún momento, los actores miran al objetivo y llegan a indicarle de viva voz hacia donde debe enfocar para rodar lo realmente relevante ("ivaya operador!", se le dice). Por si esto fuera poco, este universo ridículo -" iDios nos coja confesados!" suspira el locutor de los créditos antes de que el film comience y un letrero nos informe del agradecimiento de la producción "a las Reales Fuerzas Armadas de Figueira de Muxols, por no habernos molestado durante el rodaje de esta película" (Fig. 11) - que incluye a un "niño crecidito" llamado "Manolito Requena" (el orondo actor Manuel Requena), contratado como botones y que resulta ser el tío no fallecido de los Boliche (Fig. 12), se ve una y otra vez interrumpido por apariciones de actores y actrices hablando de la emisión con sus propios nombres y apellidos, desde la que se supone que es su casa y en la que la cámara penetra con total impunidad para sorprenderlos en actitudes privadas, incluso sorprendentemente "familiares".

Recordemos, finalmente, que es muy frecuente que rasgos del MEPR se entremezclen con elementos de otros modelos, creando híbridos tan extraños como fascinantes. Así, no debe sorprender que el que quizás sea uno de sus segmentos culminantes (la secuencia del ci- 


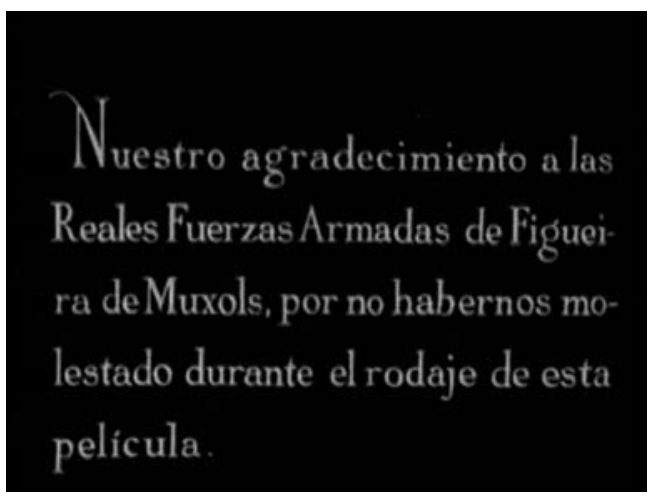

Fig. 11 La parodia absoluta reina, desde los mismos créditos, en Pototo, Boliche y compañía (Ramón Barreiro, 1948)

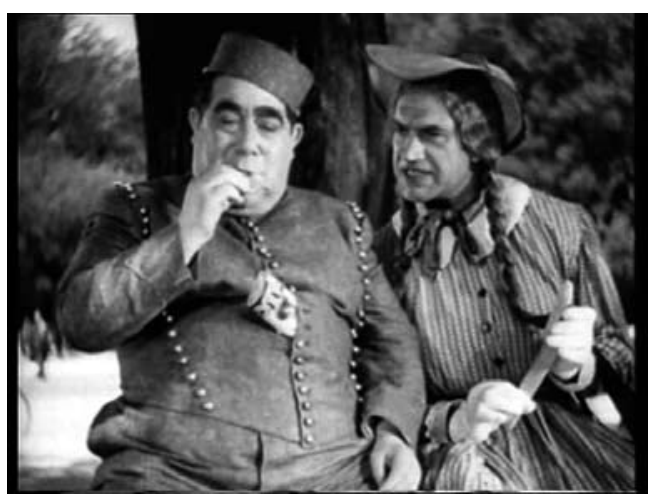

Fig. 12 El niño Manolito Requena (Manuel Requena) y el anarquista León Boliche (José Jaspe) en Pototo, Boliche y compañía (Ramón Barreiro, 1948)

nematográfico "viaje en el tren" sin salir de la cama del Edgardo de Eloísa esta debajo de un almendro) esté situado en una película que, pese partir de la obra homónima de Jardiel Poncela, presenta asimismo rasgos costumbristas y melodramáticos que la aproximan también a otros grandes títulos de su director Rafael Gil (Huella de luz, El clavo); ni que un título de enorme trascendencia histórica como El destino se disculpa, de José Luis Sáenz de Heredia y basado en un relato de Fernández Flórez, salpicado aquí y allá de elementos paródicos y reflexivos, sea capaz de recurrir alternativa y fructíferamente a elementos de los demás modelos citados hasta ahora, aunque ello imposibilite situarlo cómodamente en uno solo.

\section{2d. Modelo de estilización formalista- pictórico.}

Ya definidas sus características con maestría por diversos autores ${ }^{28}$, aun sin articularlo como Modelo de estilización, está compuesto por filmes centrados casi siempre en acontecimientos históricos bien conocidos por el público -pues su celebridad los ha convertido ya en exitosos dramas teatrales y/o decimonónicas pinturas de Historia, pasando a engrosar las leyendas populares y vulgarizando y popularizando su iconografía (almanaques, postales ilustradas, libros de texto, etiquetas de productos)-, al que entonces se le pide que reviva (y sufra, pues se nos introduce casi siempre en un universo melodramático) la historia más que dársela a conocer, y articulados con frecuencia narrativamente del final al principio, apelando al flash-back y a la voz en off de un personaje (o a la voice- over de un narrador extradiegético) que nos cuenta lo sucedido, rememorándolo.

Su puesta en escena tiende a una composición estática y pictórica del plano, produciéndose dificultades para el habitual engrase sintagmático con otras composiciones plásticas propio del montaje cinematográfico tradicional. Porque a diferencia del análisis espacial y de la continuidad del MRI -incluso, en el límite, oponiéndose a él- el montaje del MRFP se presenta como una sucesión de cuadros y láminas vivientes elaborados a partir de una tradición visual principalmente pictórica, citada muchas veces de modo literal. Resultado de una enunciación autoritaria y potentísima, este formalista plano pictórico que preside el Modelo se quiere autónomo y autosuficiente -aunque, por supuesto, termine cediendo siempre al empuje de un montaje que, con todo, se resiente sobremanera de tal resistencia a su voracidad sígnica y narrativa-, elemento prioritario de sus metalingüísticos sistemas textuales, privilegiando efectos de rigidez espacial y reencuadre en contraposición a las composiciones de fácil engrase analítico del MRI, que con todo no desaparecerán. El plano autárquico del modelo será preferentemente general o de conjunto y de extraordinaria complejidad iconográfica, lo que determinará un especial cuidado en la elaboración de decorados, figurines y vestuario. Los actores responderán al 
reto formalista-pictórico con un bien calculado histrionismo, alcanzando un tono declamativo de marcada teatralidad operística, acorde con unos movimientos sutilmente coreografiados para formar parte de tan antirrealista como subyugador universo de sentido.

Desde luego, dos títulos dirigidos por Juan de Orduña en los últimos años de la década para CIFESA, Locura de amor (1948) y Agustina de Aragón (1950), ambas protagonizadas por una tan ajustadamente excesiva como inolvidable Aurora Bautista, representan hasta tal punto el modelo que este podría parecer caracterizado para darles cabida, pero sus rasgos aparecen, con mayor o menor peso y enjundia, en otras películas más tempranas del periodo, tanto en las que podríamos denominar "históricas" ( $E /$ abanderado, Eusebio Fernández Ardavín, 1943; Reina Santa, Rafael Gil, 1946) como en singulares melodramas que parecen recibir del modelo ciertas rigideces composicionales, una vez que apelan a bien conocidas y mitificadas particularidades históricas de la región donde se ambientan (Altar Mayor, 1943, Gonzalo Pardo Delgrás, en la Asturias de Don Pelayo). E incluso el excelso "grabado fílmico" Don Quijote de la mancha (Rafael Gil, 1948) responde explícitamente a la voluntad ya no sólo de reproducir las ilustraciones clásicas de Doré o Herman Paul, sino de convertirse él mismo en fijador iconográfico del clásico cervantino; una y otra vez, por ejemplo, Gil localiza al personaje en un mundo "realista", nítido, con generosa profundidad de campo, para tratar de inmediato de reencuadrarlo, de atraparlo en poses quijotescas, reenmarcado por la estructura de un pozo, el dintel de una puerta o el vano de una ventana. ${ }^{29}$

En el caso de Orduña, la operación consiste en utilizar la imaginería popular gestada a partir de ciertos referentes visuales y darle vida fílmicamente, apoyándose en formas narrativas sólidamente reconocidas por el público; una operación irreprochable sobre el papel y mayoritariamente aceptada cuando lo ingredientes se mezclaron adecuadamente. Locura de amor, por ejemplo, parte no de los acontecimientos de la Historia, sino de los signos que popularmente contribuyeron a construir la leyenda romántica, intemporal, de la historia de amor de Juana la Loca y Felipe el Hermoso. No parece necesario insistir en las bien estudiadas fuentes plásticas de la película: la pintura flamenca del siglo XV y la pintura histórica española del siglo XIX. La ambientación general y el vestuario (obra de Manuel Comba, hijo de Juan Comba García, pintor de cámara en las cortes de Alfonso XII y Alfonso XIII, y biznieto del pintor Eduardo Rosales) y los treinta suntuosos decorados de Sigfrido Burmann construidos por Bronchalo, buscan la inscripción del film en una época determinada a través de citas de la pintura flamenca del XV y de la pintura gótica española. Así, por ejemplo, el cuadro gótico que se adivina detrás de Juana en el castillo remite al Tríptico de la Asunción de la Virgen del flamenco Albert Bouts (1460-1549), del mismo modo que se nota la influencia de Van Eyck en algunos decorados que remiten a obras como, por ejemplo, el Tríptico de Dresde (1437). Pero no todo es cita o referencia explícita en la película, siendo no menos importante considerar un trabajo sobre la disposición de la cámara, cuyo punto de vista, en ocasiones reproduce el de muchas pinturas flamencas, como la famosa Crucifixión en una iglesia (hacia 1445) de Rogier Van der Wayden, o La Virgen en una iglesia (1437-1439) de Jan o Huber Van Eyck. Por su parte, la pintura decimonónica española se había apoderado del tema romántico de Juana la Loca para plasmarlo en cuadros como Juana la Loca en Tordesillas, de Francisco Pradilla -del que, literalmente, nacen los créditos del film- (Fig. 13, Fig. 14), Locura de Doña Juana, de Lorenzo Vallés o Juana la Loca en Tordesillas, de Vicente Palmaroli. Pero hay otras muchas citaciones pictóricas en la película y una de ellas, por ejemplo, es la que utiliza, para poner en escena la muerte de la madre de Jua-

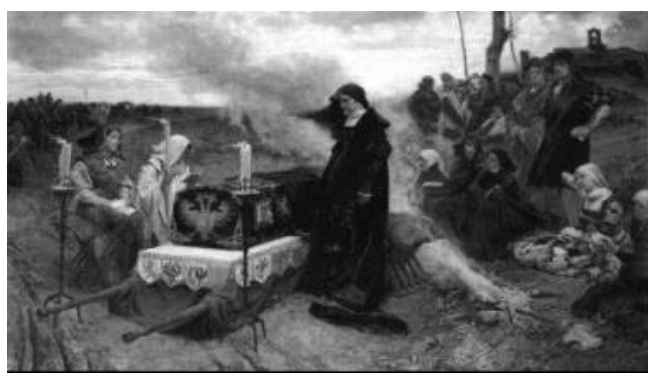

Fig. 13 Juana la Loca en Tordesillas (Francisco Pradilla, 1878, Museo del Prado) 


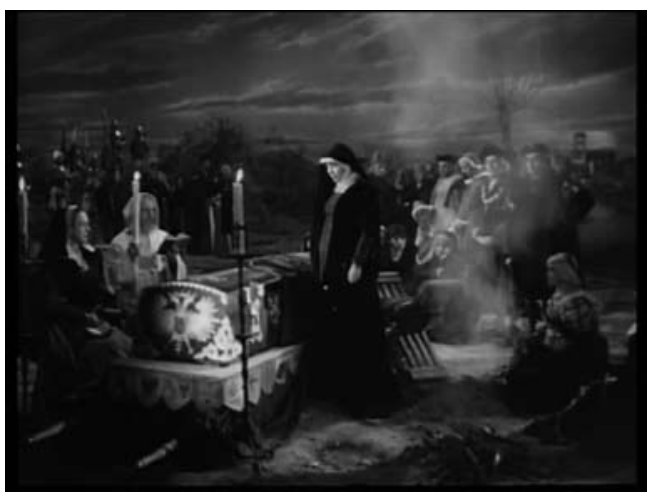

Fig. 14. Imagen que acompaña los créditos de Locura de amor (Juan de Orduña, 1948)

na, el cuadro El testamento de Isabel la Católica, pintado en 1864 por el citado Eduardo Rosales.

De igual modo -pero ahora partiendo narrativamente antes del film de aventuras que del melodrama-, Agustina de Aragón apela también a la pintura histórica española del siglo XIX (Agustina de Aragón, Juan Gálvez, 1810; La heroína Agustina Zaragoza, Marcos Hiráldez Acosta, 1871) y obtiene el máximo partido plástico de los decorados de Francisco Prosper que reconstruyen con minuciosidad la capital aragonesa de la época a partir de las pinturas y los grabados más populares sobre los sitios de Zaragoza, y más en concreto, sobre la desesperada defensa por parte de la mujer de la batería de artillería situada en la Puerta del Portillo el 2 de julio de 1808.

\section{Modelos, rugosidades, heridas.}

Los Modelos de estilización que proponemos para el estudio del cine de la posguerra permiten comprobar el alcance cultural y la extrema complejidad histórica y estética de un cine mucho más interesante que lo todavía hoy comúnmente admitido. Tras el análisis fílmico e histórico de las películas llevado a cabo en investigaciones anteriores, hemos tratado ahora de profundizar en el conocimiento de las formas, las medidas y las proporciones en las que las tradiciones culturales propias y su desarrollo histórico en el periodo posbélico contribuyeron a dar cuerpo -sobre la base del Modo de Representación Institucional $y$, en menor medida, de otros modelos internacionales- a su particularísima textura, sus formulaciones visuales y sus insistencias (y ausencias) temáticas. Se trata, en fin y una vez más, de ahondar en el conocimiento de un cine herido, a la vez humorístico y desolado, costumbrista y melancólico, reflexivo y espectral.

\section{NOTAS}

1 Este trabajo se ha realizado en el ámbito del proyecto de investigación I+D+l "Hacia una reconsideración de la cultura posbélica: análisis de los Modos de Representación en el cine español (1939-1962) a partir de la impronta de Wenceslao Fernández Flórez" (CSO2012-34648). Ministerio de Economía y Competitividad. Gobierno de España.

2 Pueden consultarse, además de un buen número de artículos, capítulos de libros, ponencias y comunicaciones escritas durante este largo periodo, los dos libros que dedicamos al tema, Un cinema herido. Los turbios años cuarenta en el cine español (1939-1950), Barcelona, Paidós, 2002, y el reciente y mucho más extenso y completo Som- bras desoladas. Costumbrismo, humor, melancolía y reflexividad en el cine español de los años cuarenta (19391950), Shangrila, Santander, 2012. Para la elaboración de este trabajo fue fundamental la aportación intelectual de Alejandro Montiel Mues ("Mal comido y peor cenado. Intercambio epistolar entre Alejandro Montiel y José Luis Castro de Paz en torno a los Modelos de estilización en el cine español de la posguerra", inédito).

3 J. Pérez Perucha, "Hacia un reconsideración del cine español", en J. Pérez Perucha (comp.), Huellas de luz. Películas para un centenario, Diorama/ Asociación Cien años de Cine, Madrid, 1995, pp. 13-20.

${ }^{4}$ Como es lógico, partimos del hecho evidente de que estudiamos un cine realizado bajo una dictadura conservadora que desarrolla sistemas simultáneos de protección económica y de férrea censura ideológica. Pese a ello, y contra lo que ha menudo se ha afirmado, la producción buscará en lo posible-aunque no siempre con acierto, dadas las dificultades- el mantenimiento de una fértil continuidad con unas tradiciones culturales propias que habían venido desarrollándose ya desde el cine mudo y la Segunda República. Lo folclórico en general y lo sainetesco en particular (la extraordinaria obra del director Edgar Neville, sobre la que hemos de volver, con títulos como La torre de los siete jorobados, 1944 o Domingo de carnaval, 1945), por ejemplo, lucharán por mantener su presencia en un cinema herido en el que el dolor de la guerra se hace presente en todos lo géneros, incluida la comedia 
(Huella de luz, Rafael Gil, 1942, a partir del relato de Wenceslao Fernández Flórez). La ya conocida productora CIFESA y la emergente Suevia Films, fundada en 1941 por el gallego Cesáreo González, serán las más fuertes empresas cinematográficas de una época compleja y excepcionalmente dura.

${ }^{5}$ En su célebre El tragaluz del infinito (Cátedra, Madrid, 1987) Noël Burch combina el estudio formal del cine y de las condiciones socio-económicas en que este se surge y se desarrolla y analiza de qué manera la progresiva consolidación de la narratividad y la ilusión de realidad no tenían nada que ver con unos supuestos y naturales principios visuales impuestos por la cámara, sino con la hegemonía de los hábitos culturales de la burguesía de la época. Emprende para ello el análisis de lo que denomina Modo de Representación Institucional (MRI), concepto que utiliza como sistema teórico que "posee una dimensión diacrónica y otra textual" para referirse al complejo entramado de principios, normas y orientaciones que constituyen la organización global de ese gran edificio narrativo, retórico y espectacular que es el cine hollywoodiense (N. Burch, El tragaluz del infinito, Cátedra, Madrid, 1986). Cercano al concepto de Modo de Representación burchiano se encuentra el de Modo de Práctica Fílmica, que David Bordwell, Kristin Thompson y Janet Staiger construyen en su monumental El cine clásico de Hollywood. Estilo y modo de producción hasta 1960 (original en 1985, traducción española, Paidós, Barcelona, 1997). Se trata de dos nociones cercanas que se corresponden con las tentativas iniciales, a la postre extraordinariamente fructíferas, de ensamblar análisis estilístico e historia del cine. Cfr. también, la voz "Modo de representación" en J. Aumont y $\mathrm{M}$. Marie, Diccionario teórico y crítico del cine, La Marca, Buenos Aires, 2006, pp. 147. No olvidemos, en cualquier caso, que buena parte de las normas del Modo de Representación Institucional, sin duda convencional e históricamente fechado, responden a la vez a un cierto sentido común representacional que permite a los cineastas de diferentes países y en distintos periodos -pese a todos los embates modernos y posmo- dernos- ubicar dichos convencionalismos en un contexto extremadamente flexible y, al mismo tiempo, susceptible de facilitar al máximo su manejo a la hora de dirigir al espectador en la siempre compleja tarea de contrastar el significado (cfr. S. Zunzunegui, La mirada cercana. Microanálisis filmico, Paidós, Barcelona, 1996).

${ }^{6}$ Compartimos con Santos Zunzunegui (Historias de España. De qué hablamos cuando hablamos de cine español, Institut Valenciá de Cinematografía Ricardo Muñoz Suay, Valencia, 2001) la convicción de que el cine español más rico y singular lo es por su profunda estilización, utilizando dicha expresión en el sentido en que la usa Pedro Salinas cuando señala la existencia de una importante tradición en el arte español que supone "un desvío de la técnica meramente reproductiva del realismo" mediante la imposición a las apariencias de un "patrón estético, moral o intelectual". Como muy dice el mismo Salinas hablando de Goya, el gran arte español pasa sobre el cadáver del realismo para, de esta manera, apuntar hacia el fondo de las cosas (P. Salinas, "Significación del esperpento o Valle Inclán, hijo pródigo del 98", en Literatura española siglo XX, Alianza Editorial, Madrid, 1970, pp. 86-114). Asimismo, citando a Ortega y Gasset, Zunzunegui situaba el origen de dicha dimensión estilizada en una progresiva y espontánea labor de educación y estilización de sus formas artísticas tradicionales que la plebe española habría llevado a cabo desde el último tercio del siglo XVII y que no solo hallaría campo de expresión en el teatro "sino que propició la aparición de auténticas actitudes (patentes en el repertorio cotidiano de posturas y gestos) en las que se expresaba un vivir en forma, un existir con estilo". Sobre esa estilización -que toma cuerpo en las variadas formas del teatro popular castizo y de los espectáculos de variedades- se construiría buena parte de la escuela interpretativa de nuestros actores más relevantes, transformándose -pero manteniendo sólidos hilos con la tradición- al entrar en contacto con el cinematógrafo.

7 Por resumir muy brevemente (dada su condición, a estas alturas, de clasificación clásica): en primer lugar, los que "huyen del realismo primario por la vía de la exageración, de la deformación sangrante" o esperpéntica (Berlanga/Ferreri/Azcona, FernánGómez); en segundo, el popularismo casticista, sainetesco, encabezado por Edgar Neville y en el que cobran importancia singular las tradiciones del género chico, especialmente sus tipos actorales; en tercer lugar, la vía del mito, que se despliega en obras aisladas (Vida en sombras de Lorenzo Llobet-Gràcia o la obra de Carlos Serrano de Osma serían buenos ejemplos en la posguerra) hasta alcanzar su cénit en dos títulos señeros durante la transición: El espíritu de la colmena (Víctor Erice, 1973) y Furtivos (José Luis Borau, 1975); y, finalmente, los extraterritoriales que, como Pere Portabella, mezclan armoniosamente la vanguardia con lo popular, "la experimentación más osada con las referencias tradicionales" (S. Zunzunegui, Historias de España. De qué hablamos cuando hablamos de cine español, Institut Valenciá de Cinematografía Ricardo Muñoz Suay, Valencia, 2001).

${ }^{8}$ V. Sánchez-Biosca, Sombras de Weimar. Contribución a la historia del cine alemán 1918-1933, Verdoux, Madrid, 1991, p. 29.

9 J. L. Castro de Paz, "La huella de la pintura en el cine español tras la Guerra Civil", Secuencias. Revistas de Historia del cine, $n^{\circ} 27$ (2008), pp. 7-22.

$10 \mathrm{~J}$. Talens y S. Zunzunegui (eds.), Modes of Representation in the Spanish Cinema, University of Minnesota Press, Minneapolis/London, 1998.

11 J. L Castro de Paz y J. Cerdán, "Tra(d)iciones y traslaciones del ensayo fílmico en España (algunas ideas en torno a la condición autorreflexiva de nuestro cine desde una perspectiva histórica)" en A. Weinrichter (ed.), La forma que piensa. Tentativas en torno al cine ensayo, Gobierno de Navarra y Museo de Arte Reina Sofía, Navarra, 2007.

12 Daniel Sánchez Salas, en su destacado trabajo sobre las fuentes literarias del cine mudo español y refiriéndose a nuestros trabajos previos, ha señalado la relevante pertinencia de "la argumentación a favor de la línea 
de continuidad que puede detectarse entre la cinematografía española de los años treinta y la de los cuarenta, debida a la presencia común de aspectos importantes de la cultura popular española de tradición social más arraigada", señalando como dicha continuidad únicamente encuentra su auténtico sentido "si su origen queda localizado en la cinematografía madrileña de los años veinte, donde en gran medida se incorporan y en general se constituyen como elementos cinematográficos esos aspectos de la cultura popular, así como muchas de las historias adaptadas de la narrativa que los vehicularon y varios de los cineastas que trabajaron en ellas hasta, por lo menos, los años cuarenta, como Juan de Orduña, Florián Rey y Benito Perojo (D. Sánchez Salas, Historias de luz y papel. El cine español de los años veinte, a través de su adaptación de narrativa literaria española, Filmoteca Regional Francisco Rabal, Murcia, 2007, pp. 213-214)

13 J. L. Castro de Paz, "Un fértil humus literario entre la aurora y la melancolía: las dos versiones de El malvado Carabel de Wenceslao Fernández Flórez (Edgar Neville, 1935; Fernando FernánGómez, 1955)", en J. Pérez Perucha y A. Rubio Alcover (eds.), Actas del XIII Congreso de la Asociación Española de Historiadores del Cine. Aurora y melancolía. O cine español durante a ll República, Vía Láctea, A Coruña, 2011.

${ }^{14}$ S. Zunzunegui, "Epílogo. La línea general o las vetas creativas del cine español", en J. L. Castro de Paz, J. Pérez Perucha y S. Zunzunegui, La nueva memoria. Historia(s) del cine español, Vía Láctea, A Coruña, 2005.

${ }^{15}$ Una aproximación preliminar a las raíces sainetescas del cine español puede consultarse en J. A. Ríos Carratalá, Lo sainetesco en el cine español, Universidad de Alicante, Alicante, 1997. Cfr. también el capítulo 8 de nuestro Sombras desoladas, ya citado.

16 Porque de hecho, aunque el Modelo de estilización sainetescocostumbrista continuará transitándose, entre 1951 y 1959 ciertos cineastas afrontarán, partiendo de ese material costumbrista y de las experiencias de Neville, un proceso de crispación y distanciamiento de la mirada, un cami- no hacia una intransferible y reflexiva modernidad ibérica, grotesca y esperpéntica, similar en cierto sentido al llevado a cabo, en sus artes y en su día, por artistas y escritores como Francisco Goya o Ramón María del Valle-Inclán. Lo estudiamos con detenimiento en J. L. Castro de Paz y J. Cerdán, Del sainete al esperpento. Relecturas del cine español de los años 50, Cátedra, Madrid, 2011, tratando de sacar a la luz las huellas de esa crispada mirada ibérica que, desde arriba y con rabia, distorsiona los rasgos del mundo inicialmente costumbrista que observa para mejor mostrar, así y de nuevo, la triste realidad española.

17 J. M. Company, "Edgar Neville", en J. L. Borau (dir.), Diccionario del cine español, Alianza Editorial/Academia de las Artes y las Ciencias Cinematográficas de España, Madrid, 1998, pp. 620-621.

${ }^{18}$ M. Bajtin, La cultura popular en la Edad Media y el Renacimiento, Alianza, Madrid, 1998.

${ }^{19} \mathrm{Cfr}$. J. L. Castro de Paz y H. Paz Otero, "Ricardo Gascón and His Brazen Vision of Wenceslao Fernández Flórez: Ha entrado un ladrón (1949)", Cine y... Journal of Interdisciplinary Studies of Film in Spain, vol. 3, no 1-2 (2010), pp. 123-131. Sobre el no demasiado llamativo pero destacado papel de Fernández Flórez en la configuración del Modelo de estilización obsesivo-delirante, consúltese H. Paz Otero "Aportaciones melodramáticas de Wenceslao Fernández Flórez al Modelo de estilización obsesivo-delirante en el cine español posbélico", en J. Pérez Perucha y A. Rubio Alcover (eds.), Actas del XIV Congreso de la Asociación Española de Historiadores del cine. De cimientos y contrafuertes. El papel de los géneros en el cine español, AEHC, Bilbao, 2013, realizado en el marco de nuestro proyecto de investigación.

${ }^{20}$ Aunque somos conscientes de que el delirio está estrechamente vinculado a la psicosis, mientras es en extremo extraño en la neurosis obsesiva, utilizamos los términos en sentido no estrictamente psicoanalítico. Aun así, no faltan casos de alucinaciones y delirios agudos, no psicóticos, también debidos a un desorden de la simbolización de la experiencia de la castración y que, por tanto, podrían esclarecerse a través de la hipótesis de la forclusión. En nuestro Modelo, el retorno de la representación continúa siendo una representación del yo, de naturaleza simbólica, mientras en la psicosis lo rechazado y lo que retorna son profundamente heterogéneos (Cfr. J. D. Nasio, Enseñanza de 7 Conceptos Cruciales del Psicoanálisis, Gedisa, Barcelona, 1996)

${ }^{21}$ Núcleo temático universalmente melodramático pero significativamente presente también en muchas otras películas de la década solo parcialmente "afectadas" por el Modelo, como las muy destacadas y disímiles El clavo (Rafael Gil, 1945), a partir del relato de Pedro Antonio de Alarcón o la opera prima de Manuel Mur Oti Un hombre va por el camino, rodada en 1949

${ }^{22}$ Los thrillers urbanos, oscuros y apesadumbrados, escritos por Miguel Mihura y dirigidos por su hermano Jerónimo (Siempre vuelven de madrugada, 1948) o por Rafael Gil (La calle sin sol, 1948; Una mujer cualquiera, 1949) incluyen siempre una brutal fractura elíptica -solo desvelada en el flash-back final-, creciente agujero negro narrativo que convierte el film en un malsano y enmarañado tejido de huidizas miradas, tensiones y temores entre los personajes (y el espectador).

${ }^{23}$ Gómez Tello, J. L., "Ante el estreno triunfal de El clavo. Las tres dimensiones de una gran película española", Primer plano $\mathrm{n}^{\circ} 208$ (8 de octubre de 1944). Un detenido estudio de la cuestión en J. L. Castro de Paz: "Cuerpo(s) para nuestras letras: Rafael Gil y CIFESA (1940-1947), en J. L. Castro de Paz (coord..), Rafael Gil y CIFESA. El cine que marcó una época, Generalitat Valenciana, Valencia, 2006. Consúltense también los capítulos correspondientes de nuestro Sombras desoladas, ya citado, y el destacado artículo de F. González, "El clavo, de Rafael Gil en la búsqueda de un modelo para el cine español", Archivos de la Filmoteca, $\mathrm{n}^{\circ} 45$ (octubre, 2003), págs. 74-93.

24 J. Pérez Perucha, "Embrujo", en VV. AA., Los mejores cien años de nuestra vida (1995), p. 90.

${ }^{25}$ A. Montiel Mues; "Algo sobre E. García Álvarez y el cine español", en J. 
N Pérez Perucha y A. Rubio Alcover (eds.),

口. Actas del XIV Congreso de la Asociación

() Española de Historiadores del cine. De

cimientos y contrafuertes. El papel de

은 los géneros en el cine español, AEHC,

क Bilbao, 2013, realizado en el marco de

$\mathcal{U}$ nuestro proyecto de investigación.

.0 ${ }^{26}$ S. Kozloff, Invisible Storytellers:

$\exists$ Voice-over Narration in American Fic-

' tion Film, University of California Press,

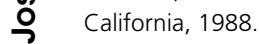

27 J. L. Castro de Paz y X. Fandiño (eds.), Ramón Barreiro. Humor, parodia e modernidade, CGAI/Filmoteca de Galicia, A Coruña, 2009.

${ }^{28} \mathrm{Cfr}$., muy especialmente, J. L. TéIlez, "De historia y folklore (notas sobre el $2^{\circ}$ periodo Cifesa)", en J. Pérez Perucha (coord.), Cifesa: de la antorcha de los éxitos a las cenizas del fracaso, Archivos de la Filmoteca $n^{\circ} 4$ (diciembrefebrero, 1990), recientemente reeditado en J. L. Téllez, Paisajes imaginarios. Escritos sobre música y cine, Cátedra, Madrid, 2013, pp. 305-314. También, J. C. Seguin, "Locura de amor (1948)", en J. Pérez Perucha, Antología critica del cine español (1906-1995), Cátedra, Madrid, 1997, pp. 230-232.

29 J. L. Castro de Paz, "Realismos, grabados o.... 'una espesa cortina de incienso' (a propósito de Don Quijote de la Mancha)", en Carlos F. Heredero (ed.), Espejos entre ficciones. El cine y el Quijote, Ministerio de Cultura/Sociedad Estatal de Conmemoraciones Culturales, Madrid, 2009, pp. 189-200. 